\title{
Clinical characteristics and overdose risk factors of patients hospitalized due to warfarin overdose
}

\author{
Varfarin doz aşımı nedeniyle kliniğe yatırılan hastaların \\ klinik özellikleri ve doz aşımı ile ilgili risk faktörleri
}

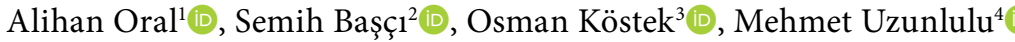 \\ ${ }^{1}$ Department of Internal Medicine, Demiroğlu Bilim University, Faculty of Medicine, Istanbul, Turkey \\ ${ }^{2}$ Department of Hematology, University of Health Sciences, Dr. Abdurrahman Yurtaslan Ankara Oncology \\ Training and Research Hospital, Ankara, Turkey \\ ${ }^{3}$ Department of Internal Medicine, Division of Oncology, Trakya University, Faculty of Medicine, Edirne, Turkey \\ ${ }^{4}$ Department of Internal Medicine, Medeniyet University, Goztepe Training and Research Hospital, Istanbul, Turkey
}

\begin{abstract}
Objectives: This study aims to investigate the relationship between overdose and patient characteristics by specifying characteristics such as age, gender, comorbidity, laboratory, diet, and treatment in patients hospitalized due to warfarin overdose.

Materials and methods: A total of 167 (91 males, 76 females, mean age $77 \pm 12$ years; range 26 to 94 years) consecutive patients hospitalized at the Göztepe Training and Research Hospital Internal Medicine Clinic between May 2015 and May 2016 with International Normalized Ratio (INR) >3.50 were included in the study. Demographic data, comorbidity states, warfarin indications, thromboembolic risk scoring (CHA $2 \mathrm{DS}_{2}-\mathrm{VASC}$, bleeding risk score (HASBLED), laboratory parameters and previous hospitalizations for the same cause, current medications, diet, and bleeding origin of patients were documented.

Results: The most common warfarin indication was atrial fibrillation and the most common comorbidity was hypertension. Mean warfarin dosage was $30.8 \pm 8.7 \mathrm{mg} /$ week. Mean CHADS2-VASC was 4.2 \pm 1.2 , mean HASBLED was $3.6 \pm 0.9$, mean INR was $8.0 \pm 3.6$, and mean Time in Therapeutic Range (TTR) was $28.7 \pm 22.6 \%$. The most common drug with warfarin interaction were proton pump inhibitor. A total of $68.9 \%$ of patients were found to be using over five medications and $\% 21.6$ of patients consuming food with possible warfarin interaction. Rate of rehospitalization due to warfarin overdose was \%28.7. Bleeding frequency was \%58.1. Mean INR and HASBLED was higher and mean TTR ( $p=0.04)$ was lower in patients with bleeding compared to non-bleeding patients $(p=0.007, p<0.001)$. Male gender $(p=0.007)$ and high HASBLED score $(p<0.001)$ were independent risk factors for bleeding.

Conclusion: In inpatients hospitalized due to warfarin overdose, medications, and consumption of foods interacting with warfarin were found to be frequent; almost one third of patient were rehospitalized due to warfarin overdose, and high HASBLED score, and low TTR was associated with higher bleeding risk. Keywords: Bleeding, clinical characteristics, risk factors, warfarin overdose.
\end{abstract}

ÖZ

Amaç: Bu çalışmada varfarin doz aşımı nedeniyle yatan hastaların yaş, cinsiyet, komorbidite, laboratuvar, diyet ve tedavi gibi özellikleri belirlenerek, doz aşımı ile hastaların özellikleri arasındaki ilişki araştırıldı.

Gereç ve yöntemler: Çalışmaya Göztepe Eğitim Araştırma Hastanesi İç Hastalıkları Kliniği'ne Mayıs 2015 - Mayıs 2016 tarihleri arasında yatışı olan ve herhangi bir nedenle varfarin kullanıp uluslararası normalleştirilmiş oranı (INR) >3.50 saptanan ardışık 167 hasta (91 erkek, 76 kadın, ort. yaş $77 \pm 12$ yıl; dağılım, $26-94$ yıl) dahil edildi. Hastaların demografik verileri, eşlik eden hastalık durumları, varfarin endikasyonu, tromboemboli risk skoru (CHA 2 DS 2 -VASc), kanama riski skoru (HASBLED), laboratuvar sonuçları, daha önce aynı nedene bağlı yatışları, kullandıkları ilaçlar, mortalite, diyet ve kanama kaynakları kaydedildi.

Bulgular: En sık varfarin endikasyonu atriyal fibrilasyon, en sık eşlik eden hastalık hipertansiyon idi. Ortalama varfarin dozu $30.8 \pm 8.7 \mathrm{mg} / \mathrm{hafta}$ idi. Ortalama

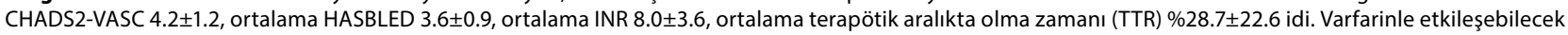
ilaç en sık proton pompa inhibitörü idi. Hastaların \%68.9'unun 5'ten fazla ilaç kullandığı, \%21.6'sının varfarin ile etkileşime girebilecek riskli olabilecek yiyecek tükettiği görüldü. Varfarin doz aşımı nedeniyle tekrar yatış oranı \%28.7 idi. Kanama sıklığı \%58.1 idi. Kanaması olan hastalarda INR ve HASBLED ortalamaları kanaması olmayanlara kıyasla yüksek $(p=0.007, p<0.001)$, TTR ortalaması düşük $(p=0.04)$ idi. Erkek cinsiyet $(p=0.007)$ ve HASBLED skoru yüksekliği ( $p<0.001)$ kanama için bağımsız risk faktörleri idi.

Sonuç: Varfarin doz aşımı nedeniyle yatan hastalarda varfarin ile etkileşebilecek ilaç ve gıda tüketiminin yüksek bulunduğu, yaklaşık her üç hastadan birinde varfarin doz aşımı nedeniyle tekrar yatış gerektiği ve yüksek HASBLED skoru ve düşük TTR kanama riskinin daha yüksek olması ile ilişkili idi.

Anahtar sözcükler: Kanama, klinik özellikler, risk faktörleri, Warfarin doz aşımı.

Received: May 13, 2019 Accepted: May 21, 2019 Published online: July 31, 2019

Correspondence: Alihan Oral, MD. Demiroğlu Bilim Üniversitesi Tıp Fakültesi İç Hastalıkları Anabilim Dalı, 34394 Şişli, İstanbul, Turkey. Tel: +90 212 - 3756565 e-mail: dr.alihanoral@gmail.com 
Warfarin is a drug commonly used in the prevention and treatment of various thromboembolic diseases. It aims to provide anticoagulant effect at a level of preventing thromboembolic events without increasing bleeding risk. ${ }^{[1]}$

Warfarin shows its effects by antagonizing the effects of vitamin $\mathrm{K}$. Oral anticoagulants (OAC) block epoxide reductase enzyme which transforms inactive vitamin $\mathrm{K}$ to vitamin $\mathrm{K}$, therefore blocking gamma carboxylation and causing inactive molecules to emerge. Consequently, anticoagulant effect is achieved by reducing blood levels of active factors. ${ }^{[2]}$ Warfarin is commonly used in patients with deep vein thrombosis (DVT), pulmonary thromboembolism (PTE), stroke, recurrent infarction, prosthetic heart valve, and atrial fibrillation (AF) ${ }^{[3,4]}$

The increasing use of warfarin in various indications, unfortunately, has increased the prevalence of adverse effects as well as benefits. ${ }^{[5]}$ When International normalized ratio (INR), used to evaluate anticoagulant efficacy, is above 3, it has been determined that there is five times increased risk of bleeding. A large majority of bleeding due to warfarin toxicity does not pose a significant threat, however it may rarely cause major or life-threatening bleeding. Studies on major bleeding associated with warfarin report a rate of $3 \% .^{[6-9]}$

The most important problem faced during warfarin treatment is thromboembolic event due to failure to achieve target INR vaue, or bleeding caused by overdose. ${ }^{[10]}$ Because of warfarin's narrow therapeutic index, even small changes in daily life can cause fluctuations in anticoagulant treatment control. Many factors such as patient compliance to treatment, age, comorbidities, additional medications, vitamin $\mathrm{K}$ content of consumed foods, and unpredictable or patientspecific dose response may affect effective and reliable anticoagulant treatment. ${ }^{[1]}$

Our hospital's internal medicine clinic has frequent hospitalizations due to warfarin overdose. In this study we aimed to investigate the relationship between warfarin overdose and patient characteristics by determining clinical, age, gender, comorbidities, laboratory, diet, and treatment characteristics of patients with warfarin overdose.

\section{MATERIALS AND METHODS}

A total of 167 (91 males, 76 females, mean age $77 \pm 12$ years; range, 26 to 94 years) patients hospitalized due to warfarin overdose at the Göztepe Training and Research Hospital Internal Medicine Clinic between May 2015 and May 2016 were included in the study. Written consent was obtained from all patients before conducting the study. Appropriate permission for the study was provided by the Istanbul Medeniyet University Goztepe Training and Research Hospital Ethics Committee (Date: 05/12/2015; No. 2015/0047). The study was conducted according to principles of the Helsinki Declaration.

Inclusion criteria of the study:

1. Over age 18

2. Use of warfarin for any reason

3. INR $\geq 3.50$ and hospitalization

Exclusion criteria:

1. Liver cirrhosis

2. Under 18 years of age

Demographic characteristics and laboratory analyses of the patients who met inclusion criteria and agreed to participate in the study were documented from admission records. Comorbidities, previous hospitalizations due to the same cause, current medications, dietary features, and presence of bleeding symptoms were questioned and recorded in forms.

\section{Age-comorbidity-indications-laboratory results}

Warfarin indications, age, comorbidities, and laboratory results of the patients were documented from admission folders. Thromboembolic risk scoring $\left(\mathrm{CHA}_{2} \mathrm{DS}_{2}-\mathrm{VASc}\right)^{[12]}$ was calculated in all non-valvular atrial fibrillation (AF) patients and bleeding risk score (HASBLED) ${ }^{[13]}$ was calculated in all patients.

\section{Medications and diet}

Medications and dietary features were learned from patients or their relatives. Use of medications that could interact with or cause overdose of warfarin was considered positive for drug risk. ${ }^{[14]}$ Frequency of use of drugs considered positive was calculated. Patients were also grouped according to number of medications they used, as 1-3, 3-5, and over 5 . 
For diet, consuming of foods within the last week that had high interaction with warfarin (cabbage, spinach, chard, parsley, purslane, romaine, lettuce, chickpeas, liver, green tea, broccoli, Brussel sprouts, turnip, fish oil) was also questioned. Consuming of these foods was considered positive. ${ }^{[15]}$

\section{Bleeding characteristics}

Patients were foremost questioned on whether or not they had bleeding. Patients with bleeding were grouped as major and minor bleeding. The major bleeding group included patients with gastrointestinal, retroperitoneal, cranial, bleeding requiring intraabdominal or invasive intervention, bleeding causing decrease in hemoglobin of two units, and patients needing more than three units of blood products in transfusion. Patients aside from these criteria were included in the minor bleeding group. Bleeding origins were also documented.

\section{INR and warfarin dosage}

International normalized ratio values of the patients at initial hospitalization was recorded. Patients were grouped as INR of 3.5-4.99, $5-9.99$, and $\geq 10$. Warfarin dosage was accepted as cumulative dose (mg/week).

Table 1. Demographic and clinical characteristics of patients

\begin{tabular}{|c|c|c|c|}
\hline & $\mathrm{n}$ & $\%$ & Mean \pm SD \\
\hline Age (year) & & & $77 \pm 12$ \\
\hline $\begin{array}{l}\text { Gender } \\
\text { Male } \\
\text { Female }\end{array}$ & $\begin{array}{l}91 \\
76\end{array}$ & & \\
\hline \multicolumn{4}{|l|}{ Frequency of comorbidities } \\
\hline Hypertension & 123 & 73.7 & \\
\hline Congestive heart failure & 97 & 58.1 & \\
\hline Diabetes mellitus & 53 & 31.7 & \\
\hline Coronary artery disease & 51 & 30.5 & \\
\hline Stroke & 40 & 24.0 & \\
\hline Chronic renal failure & 36 & 21.6 & \\
\hline Chronic obstructive pulmonary disease & 28 & 16.8 & \\
\hline \multicolumn{4}{|l|}{ Warfarin indications } \\
\hline Non-valvular atrial fibrillation & 111 & 66.5 & \\
\hline Valvular heart disease & 21 & 12.6 & \\
\hline Stroke & 12 & 7.2 & \\
\hline Deep vein thrombosis-pulmonary thromboembolism & 11 & 6.6 & \\
\hline \multicolumn{4}{|l|}{ Drugs with interaction } \\
\hline Proton pump inhibitor & 64 & 38.3 & \\
\hline Acetylsalicylic acid & 28 & 16.8 & \\
\hline Cardiac glycosides & 18 & 10.8 & \\
\hline Antibiotics & 14 & 8.4 & \\
\hline Statin & 12 & 7.2 & \\
\hline Steroid & 10 & 6.0 & \\
\hline Other & 2 & 1.2 & \\
\hline \multicolumn{4}{|l|}{ Multiple drug use (piece) } \\
\hline$<3$ & 4 & 2.4 & \\
\hline $3-5$ & 48 & 28.7 & \\
\hline$\geq 5$ & 115 & 68.9 & \\
\hline Rate of consumption of risky foods & 36 & 21.6 & \\
\hline Rate of rehospitalization & 48 & 28.7 & \\
\hline
\end{tabular}

SD: Standard deviation. 
Table 2. Comparison of clinical characteristics according to bleeding presence

\begin{tabular}{|c|c|c|c|c|c|c|c|}
\hline & \multicolumn{3}{|c|}{ Bleeding } & \multicolumn{3}{|c|}{ No bleeding } & \multirow[b]{2}{*}{$p$} \\
\hline & $\mathrm{n}$ & $\%$ & Mean \pm SD & $\mathrm{n}$ & $\%$ & Mean \pm SD & \\
\hline International normalized ratio & & & $8.6 \pm 3.7$ & & & $7.1 \pm 3.4$ & 0.007 \\
\hline Time in therapeutic range & & & $26.1 \pm 22.3$ & & & $32.6 \pm 22.7$ & 0.04 \\
\hline Thromboembolic risk score & & & $4.1 \pm 1.2$ & & & $4.4 \pm 1.2$ & 0.22 \\
\hline HASBLED & & & $3.9 \pm 0.8$ & & & $3.1 \pm 0.8$ & $<0.001$ \\
\hline Warfarin dose (mg/week) & & & $31.3 \pm 9.5$ & & & $30.1 \pm 7.6$ & 0.31 \\
\hline Risky food & 22 & 22.7 & & 14 & 20.0 & & 0.71 \\
\hline Risky drugs & 89 & 91.8 & & 59 & 84.3 & & 0.14 \\
\hline
\end{tabular}

Thromboembolic risk score: $\mathrm{CHA}_{2} \mathrm{DS}_{2}$-VASc; HASBLED: Bleeding risk score.

\section{Time in therapeutic range (TTR)}

Time in therapeutic range of patients was calculated as percentage using the Rosendaal method. ${ }^{[16]}$ Time in therapeutic range $\geq 60 \%$ was considered effective dose range, while $<60 \%$ was considered outside of effective dose range.

\section{Statistical analysis}

The collected data was analyzed using the IBM SPSS version 21.0 (IMB Corp., Armonk, NY, USA) software program. Descriptive statistics were expressed as mean \pm standard deviation. Chi-square test was used to assess categorical variables. In the analysis of continuous variables, according to distribution of data, parametrically distributed data was assessed with Student's t-test for independent samples, and Mann-Whitney $\mathrm{U}$ test was used for non-parametric data. For the comparison of three groups, when there was homogeneous variance and normal distribution, ANOVA, post hoc test was used; Tukey test was used for comparisons. Pearson and Spearmann's correlation tests were used to evaluate correlation.
In the analyses, $p$ value less than 0.05 was considered significant.

\section{RESULTS}

The most common comorbidity among the patients was hypertension (HT) (73.7\%) and the most common indication was non-valvular $\mathrm{AF}$ (66.5\%). The most common medication with warfarin interaction was proton pump inhibitor (38.3\%). According to multiple drug use, 68.9\% of patients were using five or more medications. Risky foods were consumed by $21.6 \%$ of patients. Medications with risk of warfarin interaction were used by $89 \%$ of the patients. The rate of patients with previous hospitalizations due to warfarin overdose was $28.7 \%$. Other demographic and clinical characteristics of the patients is displayed in Table 1.

Sources of bleeding, in order of frequency, were gastrointestinal (36\%), hematuria (26\%), ecchymosis $(23 \%)$, epistaxis $(12 \%)$, other $(2 \%)$, and intracranial hemorrhage (1\%).

Table 3. Comparison of clinical characteristics according to major and minor bleeding

\begin{tabular}{|c|c|c|c|c|c|c|c|}
\hline & \multicolumn{3}{|c|}{ Major bleeding } & \multicolumn{3}{|c|}{ Minor bleeding } & \multirow[b]{2}{*}{$p$} \\
\hline & $\mathrm{n}$ & $\%$ & Mean \pm SD & $\mathrm{n}$ & $\%$ & Mean \pm SD & \\
\hline International normalized ratio & & & $8.2 \pm 3.8$ & & & $8.9 \pm 3.6$ & 0.23 \\
\hline Time in therapeutic range & & & $28.1 \pm 22.2$ & & & $24.8 \pm 22.5$ & 0.41 \\
\hline Thromboembolic risk score & & & $4.2 \pm 1.4$ & & & $4.1 \pm 1.1$ & 0.61 \\
\hline HASBLED & & & $4.0 \pm 0.7$ & & & $3.9 \pm 0.8$ & 0.63 \\
\hline Warfarin dose (mg/week) & & & $32.2 \pm 6.9$ & & & $30.8 \pm 10.7$ & 0.23 \\
\hline Risky food & 7 & 19.4 & & 15 & 24.6 & & 0.62 \\
\hline Risky drugs & 34 & 94.4 & & 55 & 90.2 & & 0.71 \\
\hline
\end{tabular}

Thromboembolic risk score: $\mathrm{CHA}_{2} \mathrm{DS}_{2}-\mathrm{VASc}$; HASBLED: Bleeding risk score. 


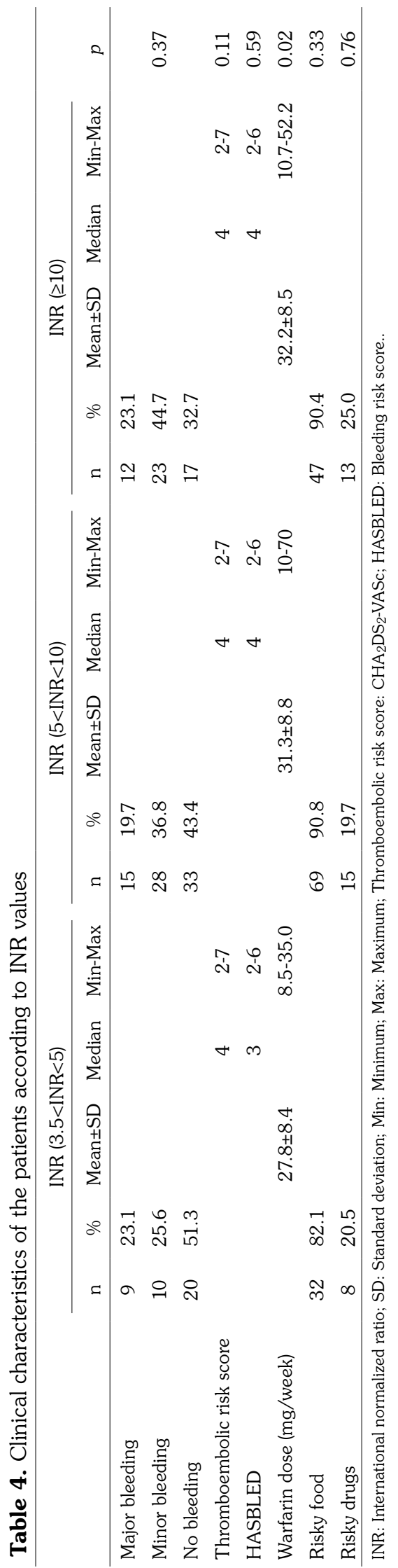

Bleeding symptoms were present in $58.1 \%$ of patients. Of these patients, while 36.5\% of all patients $(63 \%$ of patients with bleeding symptoms) showed minor bleeding, 21.6\% (37\% of those with bleeding symptoms) had major bleeding.

According to the clinical characteristics of bleeding states, patients with bleeding symptoms had statistically significantly higher mean INR $(8.6 \pm 3.7)$ compared to those who did not $(7.1 \pm 3.4)(p=0.007)$. Similarly, mean HASBLED score was also significantly higher in patients with bleeding symptoms $(3.9 \pm 0.8)$ compared to those who did not $(3.1 \pm 0.8)$. To the contrary, mean TTR was significantly lower in patients with bleeding symptoms $(26.1 \pm 22.3)$ compared to those without bleeding symptoms $(32.6 \pm 22.7)$. There was no statistically significant difference between patients with and without bleeding symptoms according to $\mathrm{CHA}_{2} \mathrm{DS}_{2}$-VASc score, warfarin dose, consuming risky foods, and use of risky medications (Table 2).

According to clinical characteristics of major and minor bleeding states in patients with bleeding symptoms, there was no difference between the two groups in terms of mean INR, HASBLED score, and TTR. Similarly, there was no difference between patients with major and minor bleeding according to warfarin dose, consuming of risky foods, and use of risky medications (Table 3).

When clinical characteristics of patients were evaluated according to INR levels, patients with elevated INR (3.5-5; 27.8 $\pm 8.4,5-10 ; 31.3 \pm 8.8$, INR $\geq 10 ; 32.2 \pm 8.5$ ) were using warfarin dosage that was significantly higher $(p=0.02)$. Presence of major bleeding, minor bleeding, no bleeding, $\mathrm{CHA}_{2} \mathrm{DS}_{2}$-VASc score, HASBLED score, eating risky foods and using risky medications were similar among the groups divided based on INR level (Table 4).

According to risk factors that could predict bleeding state, male gender $(p=0.007)$ and HASBLED score $(p<0.001)$ were observed as statistically independent risk factors (Table 5).

\section{DISCUSSION}

The increasing use of warfarin in various indications and at higher rates has unfortunately 
Table 5. Factors affecting bleeding

\begin{tabular}{lccc}
\hline & B & OR (95\%CI) & $p$ \\
\hline $\begin{array}{l}\text { Age (year) } \\
\quad 65\end{array}$ & 1.932 & $0.55-6.71$ & 0.29 \\
$\quad 65-74$ & 0.405 & $0.09-1.68$ & 0.21 \\
$\quad 75$ & 0.518 & $0.14-1.79$ & 0.30 \\
Gender & & & \\
$\quad$ Male & 2.863 & $1.32-6.18$ & 0.007 \\
International normalized ratio & & & \\
$\quad 3.5-4.9$ & 0.628 & $0.23-1.71$ & 0.35 \\
$\quad 5.0-9.9$ & 0.993 & $0.39-2.47$ & 0.98 \\
$\quad \geq 10$ & 1.593 & $0.58-4.34$ & 0.36 \\
Warfarin dose (mg/week) & 1.022 & $0.97-1.06$ & 0.31 \\
Risky food & 1.829 & $0.60-5.51$ & 0.28 \\
Risky drugs & 1.830 & $0.71-4.69$ & 0.21 \\
Time in therapeutic range & 0.989 & $0.97-1.01$ & 0.16 \\
HASBLED & 3.771 & $2.27-6.26$ & $<0.001$ \\
\hline
\end{tabular}

OR: Odds ratio; CI: Confidence interval; HASBLED: Bleeding risk score

increased the prevalence of adverse effects along with benefits. A large majority of bleeding occurring due to warfarin toxicity does not pose an important threat, however it may rarely cause major or life-threatening bleeding. In our study, bleeding due to warfarin overdose was present in over half of the patients, and it was established that it could be predicted by male gender and increased HASBLED score. Major and minor bleeding was observed to be independent from INR.

Warfarin is used to prevent thrombosis development in diseases such as AF, heart valve replacement, DVT, PTE, ischemic stroke, factor V Leiden mutation, and hyperhomocysteinemia. ${ }^{[17]}$ Many studies list AF and stroke as the top indications for warfarin use. ${ }^{[18]}$ In our study, while the most common warfarin indication was $\mathrm{AF}$, the second was heart valve replacement, and the third was stroke, differing from the literature.

In a study by Erdogan et al., ${ }^{[19]}$ comorbidities in patients presenting with warfarin overdose found HT as the most common, followed by coronary artery disease, and congestive heart failure. Shireman et al. ${ }^{[20]}$ also reported HT as the most common comorbidity. In our study, HT was also the most common comorbidity and consistent with the literature, however, congestive heart failure was the second most common, and diabetes mellitus was the third.

There is limited information in the literature on the use of drugs and food with warfarin interaction. Baykal et al. ${ }^{[21]}$ found the rate of risky drug use as $75 \%$. In our study, $89 \%$ of the patients were using at least one drug that could present a risk. The three most common drugs were proton pump inhibitors, acetylsalicylic acid, and cardiac glycosides. In addition, $68.9 \%$ of patients were using five or more drugs, and $21.6 \%$ consuming risky foods that could increase warfarin interaction and facilitate overdose. All of these may have contributed to the rehospitalization rate $(28.7 \%)$ due to warfarin overdose.

Bleeding is the most important major complication of warfarin treatment. One of the most important factors to affect bleeding risk is the intensity of anticoagulant treatment. When INR is between the range of 3.0-4.5, bleeding risk is significantly increased; when INR $>5.0$, it poses a life-threatening bleeding risk. ${ }^{[21-23]}$ Minor or major bleeding rate is reported between $7.6-16.5 \%$. Alay et al. ${ }^{[24]}$ determined that $45 \%$ of patients presenting with warfarin overdose had major bleeding and 55\% minor bleeding. According to sources of bleeding due to warfarin overdose, the most common were gastrointestinal, hematuria, 
and soft tissue bleeding, while intracranial bleeding was less common. ${ }^{[25,26]}$ Two separate studies have found gastrointestinal bleeding as the most common source at rates of $38.5 \%$ and $33.3 \% .^{[24,27]}$ In our study, $58.1 \%$ of patients had bleeding symptoms, relatively higher than in the literature, however this could be because the literature evaluated all patients using warfarin, while in our study we only evaluated patients with overdose. Of the patients with bleeding symptoms, $37 \%$ were major bleeding, and $63 \%$ were minor bleeding, and compared to the literature, major bleeding was less frequent and only one patient had mortality. In our study, the most common bleeding source was gastrointestinal bleeding at $36 \%$, consistent with the literature.

Increased INR is known to increase bleeding. ${ }^{[28]}$ Lindh et ${ }^{2} .{ }^{[29]}$ found that there was no linear relationship between INR and bleeding, while Landefeld et al. $^{[30]}$ found that every 1.0 increase in INR caused 40 times increased risk of bleeding. In a study by Veeger et al., ${ }^{[28]}$ although TTR value was not concisely determined, TTR value below 45\% compared to TTR over $65 \%$ was associated with increased risk of recurrent venous thromboembolism and bleeding. Many bleeding risk scores have been developed to determine bleeding risk in patients using warfarin. HASBLED bleeding risk score is an easy to use scoring system to determine the patient's risk of bleeding. A score of 3 or more shows high risk of bleeding. ${ }^{[13]}$ When clinical characteristics of patients in our study were evaluated according to bleeding status, INR value was significantly higher in patients with bleeding symptoms compared to those without bleeding, which was consistent with the literature. Similarly, HASBLED score was also significantly higher. Considering the components of HASBLED score are risk factors that increase bleeding, these results are not surprising. In contrast to the literature, mean TTR was significantly lower in patients with bleeding symptoms compared to those without bleeding. Since the selected patients were those with warfarin overdose, low TTR was an expected result in patients with bleeding symptoms.

One study reported significantly higher INR in patients with major bleeding compared to those with minor bleeding. ${ }^{[24]}$ In our study, when patients with bleeding symptoms were grouped according to major or minor bleeding, there was statistically significant difference in INR value. But HASBLED score, and mean TTR, they were no significantly different between patients with and without bleeding.

Regardless of overdose in patients using warfarin, it is known that many factors such as elderly age, female gender, comorbid illnesses, previous history of bleeding, eating foods or using drugs with warfarin interactions, TTR, and genetics may affect occurrence of bleeding. ${ }^{[31]}$ Studies on these risk factors present conflicting results. Shirman et al. ${ }^{[20]}$ reported that female gender and Lindh et al. ${ }^{[29]}$ that male gender was an independent risk factor for bleeding, while other studies reported that gender was not significant. In the same way, while there are studies that report that bleeding risk increases with age, ${ }^{[32]}$ there are also studies that state that age is an independent risk factor. ${ }^{[33]}$ In our study, according to risk factors that could predict bleeding state, male gender and increased HASBLED score were found as statistically independent risk factors.

In conclusion, it was observed that inpatients hospitalized due to warfarin overdose had increased food consumption and use of drugs with warfarin interaction, approximately one out of every three patients required rehospitalization due to warfarin overdose, and that patients with high HASBLED score and low TTR had increased bleeding risk.

\section{Declaration of conflicting interests}

The authors declared no conflicts of interest with respect to the authorship and/or publication of this article.

\section{Funding}

The authors received no financial support for the research and/or authorship of this article.

\section{REFERENCES}

1. Tang EO, Lai CS, Lee KK, Wong RS, Cheng G, Chan TY. Relationship between patients' warfarin knowledge and anticoagulation control. Ann Pharmacother 2003;37:34-9.

2. Göz M. Warfarin-gıda etkileşmesi: Olgu sunumu ve literatürün gözden geçirilmesi. Turk Gogus Kalp Dama 2006;14:320-4.

3. Douketis JD. Perioperative anticoagulation management in patients who are receiving oral anticoagulant therapy: a practical guide for clinicians. Thromb Res 2002;108:3-13. 
4. Grunau BE, Wiens MO, Harder KK. Patient selfmanagement of warfarin therapy: pragmatic feasibility study in Canadian primary care. Can Fam Physician. 2011;57:292-8.

5. Flaherty ML, Kissela B, Woo D, Kleindorfer D, Alwell K, Sekar P, et al. The increasing incidence of anticoagulant-associated intracerebral hemorrhage. Neurology 2007;68:116-21.

6. Granger CB, Alexander JH, McMurray JJ, Lopes RD, Hylek EM, Hanna M, et al. Apixaban versus warfarin in patients with atrial fibrillation. $\mathrm{N}$ Engl $\mathrm{J}$ Med 2011;365:981-92.

7. Patel MR, Mahaffey KW, Garg J, Pan G, Singer $\mathrm{DE}$, Hacke $\mathrm{W}$, et al. Rivaroxaban versus warfarin in nonvalvular atrial fibrillation. $\mathrm{N}$ Engl $\mathrm{J}$ Med 2011;365:883-91.

8. Connolly SJ, Ezekowitz MD, Yusuf S, Eikelboom J, Oldgren J, Parekh A, et al. Dabigatran versus warfarin in patients with atrial fibrillation. $\mathrm{N}$ Engl $\mathrm{J}$ Med 2009;361:1139-51.

9. Deitcher S, Rodgers G. Thrombosis and antithrombotic therapy. Wintrobe's Clinical Hematology. Lippincott Williams-Wilkins, 2004: 1713-58

10. Ginsberg JA, Crowther MA, White RH, Ortel TL. Anticoagulation therapy. Hematology Am Soc Hematol Educ Program 2001:339-57.

11. Davis NJ, Billett HH, Cohen HW, Arnsten JH. Impact of adherence, knowledge, and quality of life on anticoagulation control. Ann Pharmacother 2005;39:632-6.

12. Lip GY, Nieuwlaat R, Pisters R, Lane DA, Crijns HJ. Refining clinical risk stratification for predicting stroke and thromboembolism in atrial fibrillation using a novel risk factor-based approach: the euro heart survey on atrial fibrillation. Chest 2010;137:263-72.

13. Pisters R, Lane DA, Nieuwlaat R, de Vos CB, Crijns HJ, Lip GY. A novel user-friendly score (HAS-BLED) to assess 1-year risk of major bleeding in patients with atrial fibrillation: the Euro Heart Survey. Chest 2010;138:1093-100.

14. Holbrook AM, Pereira JA, Labiris R, McDonald H, Douketis JD, Crowther M, et al. Systematic overview of warfarin and its drug and food interactions. Arch Intern Med 2005;165:1095-106.

15. Booth SL, Centurelli MA. Vitamin K: a practical guide to the dietary management of patients on warfarin. Nutr Rev 1999;57:288-96.

16. Rosendaal FR, Cannegieter SC, van der Meer FJ, Briët E. A method to determine the optimal intensity of oral anticoagulant therapy. Thromb Haemost 1993;69:236-9.

17. Aguilar D, Goldhaber SZ. Clinical uses of lowmolecular-weight heparins. Chest 1999;115:1418-23.

18. Garcia DA, Regan S, Crowther M, Hylek EM. The risk of hemorrhage among patients with warfarin-associated coagulopathy. J Am Coll Cardiol 2006;47:804-8.
19. Erdoğan MÖ, Ayhan H, Çolak Ş, Duran L, Yavuz Y, Akdemir HU, et al. Epidemiological features of warfarin overdose and efficacy of prothrombin complex concentrates. J Exp Clin Med 2013:30:327-30.

20. Shireman TI, Mahnken JD, Howard PA, Kresowik TF, Hou Q, Ellerbeck EF. Development of a contemporary bleeding risk model for elderly warfarin recipients. Chest 2006;130:1390-6.

21. Baykal Y, Sağlam K, Işık AT, Erikçi S, Koçar İH. Antikoagülan ve trombolitik tedaviler. Ankara: GATA Basımevi; 2002. s. 32-47.

22. Schulman S, Beyth RJ, Kearon C, Levine MN. Hemorrhagic complications of anticoagulant and thrombolytic treatment: American College of Chest Physicians Evidence-Based Clinical Practice Guidelines (8th Edition). Chest 2008;133(6 Suppl):257S-298S.

23. Crowther MA, Ageno W, Garcia D, Wang L, Witt $\mathrm{DM}$, Clark NP, et al. Oral vitamin $\mathrm{K}$ versus placebo to correct excessive anticoagulation in patients receiving warfarin: a randomized trial. Ann Intern Med 2009;150:293-300.

24. Alay M, Demir C, Atmaca M, Esen R, Dilek İ. Oral antikoagülan tedavi seyrinde kanama komplikasyonu ile gelen hastaların değerlendirilmesi. Van Tıp Dergisi 2011;18:9-14.

25. Hamby L, Weeks WB, Malikowski C. Complications of warfarin therapy: causes, costs, and the role of the anticoagulation clinic. Eff Clin Pract 2000;3:179-84.

26. Anthony CJ, Karim S, Ackroyd-Stolarz S, Fry A, Murphy NG, Christie R, et al. Intensity of anticoagulation with warfarin and risk of adverse events in patients presenting to the emergency department. Ann Pharmacother 2011;45:881-7.

27. Emre Eroğlu S, Altınok Denizbaşı A, Özpolat Ç, Akoğlu H, Ecmel Onur Ö, Akoğlu Ünal E. The investigation of the relation between INR levels and risk of complication in patients with a history of warfarin use. Marmara Medical Journal 2012:25:138-42.

28. Veeger NJ, Piersma-Wichers M, Tijssen JG, Hillege $\mathrm{HL}$, van der Meer J. Individual time within target range in patients treated with vitamin $\mathrm{K}$ antagonists: main determinant of quality of anticoagulation and predictor of clinical outcome. A retrospective study of 2300 consecutive patients with venous thromboembolism. Br J Haematol 2005;128:513-9.

29. Lindh JD, Holm L, Dahl ML, Alfredsson L, Rane A. Incidence and predictors of severe bleeding during warfarin treatment. $\mathrm{J}$ Thromb Thrombolysis 2008;25:151-9.

30. Landefeld CS, Goldman L. Major bleeding in outpatients treated with warfarin: incidence and prediction by factors known at the start of outpatient therapy. Am J Med 1989;87:144-52.

31. González C, Penado S, Llata L, Valero C, Riancho JA. The clinical spectrum of retroperitoneal hematoma in anticoagulated patients. Medicine (Baltimore) 2003;82:257-62. 
32. McMahan DA, Smith DM, Carey MA, Zhou XH. Risk of major hemorrhage for outpatients treated with warfarin. J Gen Intern Med 1998;13:311-6.

33. Fihn SD, Callahan CM, Martin DC, McDonell MB,
Henikoff JG, White RH. The risk for and severity of bleeding complications in elderly patients treated with warfarin. The National Consortium of Anticoagulation Clinics. Ann Intern Med 1996;124:970-9. 